\title{
Hematological Profile of Indian Bullfrog and Common Toad from Different Environmental Habitats
}

\author{
Lenka Monalisa $^{1}$, Dutta Sonali ${ }^{2}$, Kar Biswakanth $^{3}$ and Pattnaik Gurudutta ${ }^{*}$ \\ ${ }^{1}$ Centurion University of Technology and Management, Odisha, India. \\ 2Department of Zoology, Stewart Science College, Cuttack, Odisha, India \\ ${ }^{3}$ School of Pharmaceutical Sciences, Siksha O Anusandhan Deemed to be University, Bhubaneswar, Odisha, India \\ *Corresponding Author
}

Received: $14^{\text {th }}$ December, 2020

Accepted: 29th January, 2021

Published online: $12^{\text {th }}$ February, 2021

https://doi.org/10.33745/ijzi.2021.v07i01.002

\begin{abstract}
The wellbeing of human population depends on the ecosystem of earth. Amphibians from the ancient time represents a major part in the global diversity and play important role for the benefit of society worldwide. The aim of the present study was to investigate the comparative hematological study of Indian bullfrog (Hoplobatrachus tigerinus) from wetland and a common Indian toad (Duttaphrynus melanostictus) from terrestrial environment. In this study we have procured 10 sexually mature and disease-free Indian bullfrog $(9.93 \pm 0.07 \mathrm{~cm}$ total length, $59.5 \pm 1.94 \mathrm{~g}$ weight $)$ and 10 common Indian toad $(8.26 \pm 0.26 \mathrm{~cm}$ total length, $78.6 \pm 1.36 \mathrm{~g}$ weight). The RBC and WBC count were found to be increased in frog than toad. Variation in RBC morphology which reveals the anemic condition in frog than that of toad. The study suggested that the environmental conditions have significant impact on status of frog and toad.
\end{abstract}

Keywords: Anura, Hematology, Environment, Conservation, Duttaphrynus melanostictus, Hoplobatrachus tigerinus

Citation: Lenka Monalisa, Dutta Sonali, Kar Biswakanth and Pattnaik Gurudutta: Hematological profile of Indian bullfrog and common toad from different environmental habitats. Intern. J. Zool. Invest. 7 (1): 17-21, 2021. https://doi.org/10.33745/ijzi.2021.v07i01.002

\section{Introduction}

Anurans (comprises both frogs and toads) are widely distributed around the world. They play an important role in ecology which include maintenance of tropic level, nutrient cycling, pest control, bio-indicator, pollinators, research tractability etc. (Valencia et al., 2013). Anurans are very sensitive to nature and any changes in their environment leads to significant variation of physiological parameters (Carey, 2005). The acute 
environmental deviations reduces the population of amphibians suggesting loss of ecosystem of earth and which is reflected in blood cells (Das and Mahapatra, 2014). The normal hematological and biochemical parameters of natural population gives idea about the health and disease status of the vertebrates. Analysis of hematological parameters like $\mathrm{RBC}, \mathrm{WBC}$, platelets and proteins will allow to find out the types of variation in ecological and environmental conditions (Young et al., 2012). These are being used as indicators in the measurement of health conditions and toxicological symptoms of organisms. Information about the status of existence and degree of possible sickness in organisms can be rapidly obtained by the use of hematological and biochemical parameters (Fazio et al., 2012). In pathological conditions, the hematological parameters are reflected by change in number or morphology of erythrocytes and lymphocytes (Muliya and Bhat, 2015). The hematological parameters would help for revealing contagious disease which causes major problems for the conservation of anurans. The present study was aimed to provide information about the hematological parameters of two anuran species Indian bullfrog (Hoplobatrachus tigerinus) and a common Indian toad (Duttaphrynus melanostictus) inhabiting wetland and terrestrial habitats, respectively.

\section{Materials and Methods}

\section{Collection, sampling and analytical methods}

The species of anurans were collected from Tigiria in the east region of Cuttack district, India $\left(20^{\circ} 29^{\prime} 0^{\prime \prime} \mathrm{N}, 85^{\circ} 31^{\prime} 0^{\prime \prime} \mathrm{E}\right)$.

Indian bullfrog (Hoplobatrachus tigerinus, $\mathrm{n}=10$ ) from wetland habitat and common
Indian toad (Duttaphrynus melanostictus, $\mathrm{n}=10$ ) from terrestrial habitat were collected. The blood samples were collected by cardiocentesis as per the standard method (Chang et al., 2015). The collected blood samples were immediately subjected to hematological analysis such as total WBC count, RBC count etc. At the end of blood sampling, weight and length of each individual were recorded (Table 1).

\section{Blood morphology}

The blood smears were prepared using push slide technique. The dried blood smears were stained with Giemsa's stain and observed under light microscope (Hund H500 WETZLAR). Different types of blood cells present in the smear were identified and photographed with the help of a camera and measured using an ocular micrometer which was standardized against a stage micrometer (ERMA, Japan made). Formulae used by Arserim and Mermer were followed for measurement of blood cells.

\section{Statistical analysis}

Differences in hematological parameters between the two anuran species were statistically analyzed by Student's t-test. Mean and standard error (SE) were calculated for each parameter. All these statistical analyses were performed by using the statistical software Prism v. 4.00 (Graph Pad Software Ltd., USA).

\section{Results}

The biometric parameters of both the species Hoplobatrachus tigerinus and Duttaphrynus melanostictus collected from different environmental habitats are shown in Table 1. The length and weight of mature healthy Indian bullfrog was found to be $9.93 \pm 0.07 \mathrm{~cm}$ 
Table 1: Biometric data of frog and toad species

\begin{tabular}{|l|cccc|ccccc|}
\hline Species & \multicolumn{4}{|c|}{ Length (cm) } & \multicolumn{5}{c|}{ Weight (g) } \\
\cline { 2 - 9 } & Mean \pm SE & Min & Max & CV(\%) & Mean \pm SE & Min & Max & CV(\%) \\
& & & & & & & & \\
\hline Frog (n=10) & $9.93 \pm 0.07$ & 9.6 & 10.3 & 2.47 & $59.5 \pm 1.94$ & 51 & 68 & 10.31 \\
& & & & & & & & \\
\hline Toad (n=10) & $8.26 \pm 0.26$ & 73 & 85 & 10.18 & $78.6 \pm 1.36$ & 73 & 85 & 5.49 \\
& & & & & & & & & \\
\hline
\end{tabular}

Table 2: Hematological parameters obtained into two experimental groups

\begin{tabular}{|c|c|c|c|}
\hline \multirow[t]{2}{*}{$\begin{array}{l}\text { Hematological } \\
\text { Parameters }\end{array}$} & Hoplobatrachus tigerinus $(\mathrm{n}=10)$ & $\begin{array}{c}\text { Duttaphrynus melanostictus } \\
(\mathrm{n}=10)\end{array}$ & \\
\hline & Mean \pm SE & Mean \pm SE & P value \\
\hline $\mathrm{RBC}\left(\times 10^{6}\right.$ cells $\left./ \mu \mathrm{l}\right)$ & $0.59 \pm 0.21$ & $0.51 \pm 0.35$ & $<0.001$ \\
\hline Total WBC & $28948.7 \pm 6.09$ & $18104 \pm 4.18$ & $<0.0001$ \\
\hline Neutrophils (\%) & $39.9 \pm 0.82$ & $22.7 \pm 1.26$ & $<0.0001$ \\
\hline Basophils (\%) & 00 & 00 & \\
\hline Eosinophils (\%) & $18.1 \pm 0.57$ & $8.5 \pm 0.69$ & $<0.0008$ \\
\hline Lymphocytes (\%) & $41.0 \pm 1.0$ & $58.4 \pm 3.07$ & $<0.0037$ \\
\hline Monocytes (\%) & 00 & 00 & \\
\hline
\end{tabular}

and $59.5 \pm 1.94 \mathrm{~g}$ and for common Indian toad was $8.26 \pm 0.26 \mathrm{~cm}$ and $78.6 \pm 1.36 \mathrm{~g}$, respectively. The hematological parameters of Hoplobatrachus tigerinus and Duttaphrynus melanostictus were mentioned in Table 2. Variations among the species were noticed in all hematological values. From the result it was found that the total WBC count in wetland frog is very high $(28948.7 \pm 6.09)$ as compared to terrestrial toad $(18104 \pm 4.18)$. Neutrophils and lymphocytes play a vital role in primary phagocytosis and increased count indicated a higher pathogenic environmental condition. High percentage of mean neutrophil was recorded in frog as compared to toad (Table 2). Increased percentage of eosinophil (18.1 \pm 0.57$)$ was noticed in frog as compared to toad $(8.5 \pm 0.69)$ (Table 2). Lymphocytes were high in toad (58.4 \pm 3.07$)$ as compared to frog $(41.0 \pm 1.0)$ (Table 2). Number of RBCs increased significantly in frog than toad (Table 2). RBC count are related to environmental factors such as water, temperature and oxygen content.

\section{Discussion}

The physic-chemical parameters of land and wetland is completely different with regards to temperature, $\mathrm{pH}$, oxygen content and moisture content. These parameters significantly affect the hematological parameters (Parida et al., 2014). In addition, the blood constituents in anurans are also influenced by ecological habitat, food selection and mode of life. Therefore, it is difficult to establish any normal values for this class as a 
whole. But, if data are collected for different species as well as within species under different conditions some normal ranges of values can be arrived at, which can form a valuable diagnostic aid. Studies of blood parameters had proven to be a valuable approach for analyzing the health status (Wei et al., 2015) of anurans and help in understanding the relationship of blood characteristics to the habitat and adaptability of the species to the environment. The ranges of normal values of the key biochemical parameters are still undefined for same type of animal living in different habitats. In the wetland habitat, the anurans homeostatic system is continuously affected by the changes of the level of moisture content, temperature, $\mathrm{pH}$ and oxygen concentration. The physiological response to environmental variations such as temperature and moisture content has been investigated in terrestrial species inhabiting wetland system. In the present study significant differences were observed in some hematological parameters between groups of frog and toad. This study showed differences in WBC values-neutrophil, eosinophil and lymphocyte in both species under present study. As anurans are very susceptible to physical and chemical changes in the environment which may be reflected in their blood components. The significant differences in some hematological parameters in the two species of anurans (frog and toad) could be attributed to different habitat conditions. The differences in WBC count in the two species of anurans could be the result of different body size of anurans as there was statistical difference in biometric data of the two species. Differences in WBC count may be attributed to many factors, both biotic (such as age, season, maturity, pathogens) and abiotic (water temperature, $\mathrm{pH}$, moisture content) and in particular to stress.

The characteristics shape of amphibian erythrocytes is mainly found to be in elliptical form in both the species (Collins et al., 2016). is study revealed that the erythrocytes of frog show different shapes including elliptical cells, circular and spindle shaped cells with centrally placed nuclei. However, toads have simple ellipsoidal shape of RBCs with very rare irregular shape of cells.

\section{Conclusion}

This study provides information about the characteristics of hematological parameters of anuran species from two different habitats. The hematological parameters may be affected by physico-chemical factors. So the environment influences the hematological profiles within same family suggesting that blood parameters may be considered in monitoring the effects of habitat changes on amphibians' biology.

\section{References}

Carey C. (2005) How physiological methods and concepts can be useful in conservation biology. Integrative Comp Biol. 45: 4-11.

Chang AG, Hu J, Lake E, Bouley DM and Johns JL. (2015) Biochemical and haematologic reference intervals for aged Xenopus laevis in a research colony. J Am Assoc Lab Anim Sci. 54: 465-470.

Collins S, Dornburg A, Flores JM, Dombrowski DS and Lewbart GA. (2016) A comparison of blood gases, biochemistry and hematology to ecomorphology in a health assessement of pinfish (Lagodon rhomboids). PeerJ 4: e2262. https://doi.org/10.7717/peerj.2262

Das M and Mahapatra PK. (2014) Hematology of wild caught Dubois's Tree Frog Polypedates teraiensis, Dubois, 1986 (Anura: Rhacophoridae). 
The Scientific World Journal 2014: 491415. http://dx.doi.org/10.1155/2014/491415

Fazio F, Palanisamy SK, Kumar DS, Faggio C and Piccione G. (2012) A comparative study of hematological and blood chemistry of Indian and Italian Grey Mullet (Mugil cephalus Linneaus 1758). Herbert Open Access J Biol. 1: 5. http://dx.doi.org/10.7243/2050-0874-1-5

Muliya SK and Bhat MN. (2016) Hematology and serum biochemistry of Indian spectacled cobra (Naja naja) and Indian rat snake (Ptyas mucosa). Vet World 9: 909-914.

Parida SP, Dutta SK, Pal A. (2014) Hematology and plasma biochemistry of wild- caught Indian cobra Naja naja. J Venom Anim Toxins Incl Trop Dis. 20:14. https://doi.org/10.1186/1678-9199-20-14
Valencia-Aguilar A, Angela M Cortés-Gómez and César Augusto Ruiz-Agudelo (2013) Ecosystem services provided by amphibians and reptiles in Neotropical ecosystem. Intern J Biodiver Sci Ecosystem Ser Manag. 9: 257-272.

Wei J, Li YY, Wei L, Ding GH, Fan XL and Lin ZH. (2015) Evolution of erythrocyte morphology in amphibians (Amphibia: Anuran). Sociedade Brasileira de Zoologia 32: 360-370.

Young S, Warner J, Speare R and Muller R. (2012) Hematologic and plasma biochemical reference intervals for health monitoring of wild Australian frog. Vet Clin Path. 41: 478-492. 